\title{
Left atrial decompression by percutaneous cannula placement while on extracorporeal membrane oxygenation
}

\author{
Anthony M. Hlavacek, MD, Andrew M. Atz, MD, Scott M. Bradley, MD, and Varsha M. Bandisode, MD, \\ Charleston, SC
}

$\mathrm{V}$

enoarterial extracorporeal membrane oxygenation (ECMO) is often used in pediatric patients with severe myocardial dysfunction, typically after cardiac surgery, or in patients with acute myocarditis. A problem frequently encountered in these patients is left atrial hypertension, which may result in pulmonary edema, ventricular distention, and subendocardial ischemia. ${ }^{1,2}$ Decompression of the left atrium (LA) will reduce diastolic pressures in the left heart, resulting in an improvement in coronary perfusion and lessen pulmonary edema. We describe the percutaneous placement of a venous cannula in the LA while on ECMO in a child with severe cardiac dysfunction as a result of myocarditis.

\section{Clinical Summary}

A 9-year-old boy, weighing $38 \mathrm{~kg}$, was transferred to our institution with severe cardiac dysfunction as a result of biopsy-proven myocarditis. Three days after admission, his cardiac function continued to deteriorate, and venoarterial ECMO was instituted through the right internal jugular vein and right carotid artery. Four days after cannulation, chest radiography revealed worsening pulmonary edema and pleural effusions. An echocardiogram confirmed LA dilation and hypertension in addition to further decline in cardiac function. While on ECMO, he was transported from the Pediatric Intensive Care Unit to the Pediatric Cardiac Catheterization Laboratory. A transesophageal echocardiogram was performed, confirming that the atrial septum was intact and bowing as the result of LA hypertension. He was prepped and draped in the standard sterile fashion, and, using the modified Seldinger technique, a 7F Mullins transseptal sheath was placed in the right femoral vein. This sheath was guided into the right atrium, and, using a Brockenbrough transseptal needle, the atrial septum was punctured under transesophageal echocardiography guidance. The mean pressure in the LA was $57 \mathrm{~mm} \mathrm{Hg}$. A 6F multipurpose catheter was advanced through the sheath and into the left ventricle. Over a guidewire, the multipurpose catheter and $7 \mathrm{~F}$ transseptal sheath were removed. The newly created atrial septal defect was

From the Medical University of South Carolina, Charleston, SC.

Received for publication Nov 18, 2004; accepted for publication Dec 23, 2004.

Address for reprints: Anthony Marcus Hlavacek, MD, Fellow, Department of Pediatric Cardiology, 165 Ashley Ave, PO Box 250915, Charleston, SC 29425 (E-mail: hlavace@ musc.edu).

J Thorac Cardiovasc Surg 2005;130:595-6

$0022-5223 / \$ 30.00$

Copyright $\odot 2005$ by The American Association for Thoracic Surgery

doi:10.1016/j.jtcvs.2004.12.029 serially dilated with $10 \mathrm{~F}$ and $16 \mathrm{~F}$ transseptal sheath dilators. With transesophageal echocardiography guidance, a $17 \mathrm{~F}$ cannula was advanced over the guidewire into the LA and connected to the venous ECMO circuit. Chest radiography confirmed resolution of his pulmonary edema by the subsequent day. An echocardiogram revealed normalization of his LA size and an estimated LA pressure decrease to $18 \mathrm{~mm} \mathrm{Hg}$ by Doppler measurement of the mitral regurgitation gradient. He remained on ECMO for 42 days until a successful orthotopic heart transplant was performed.

\section{Discussion}

Cardiac catheterizations may be performed safely in patients while on ECMO. ${ }^{3}$ Several groups have described transseptal decompression of the LA in the catheterization laboratory using blade or balloon septostomy. ${ }^{1,4}$ Another group described transseptal decompression of the left heart in an infant with a $4 \mathrm{~F}$ introducer in the LA as a connection to the venous ECMO cannula. ${ }^{2}$

The Rashkind balloon atrial septostomy is not successful in all patients because of varying degrees of atrial septal thickness; thus, many centers perform blade atrial septostomy in these children. However, the performance of blade atrial septostomy on a fully heparinized patient is not without significant risks. ${ }^{5}$ For that reason, centers including our own generally use the Brockenbrough atrial septoplasty technique with progressive static balloon dilation of the atrial septum. This procedure may be augmented by the placement of a transseptal stent. The atrial septum offers less stability for stent placement than most other structures in which stents are generally used, and stent dislodgment is a potential complication. Both methods of atrial septostomy can result in inadequate decompression and persistent LA hypertension.

We submit that LA cannulization offers several advantages over the previously mentioned options. First, unlike septostomy, the placement of a LA cannula potentially allows for a controlled decompression of the LA by adjusting flow rates on the ECMO module or clamping the cannula. Second, the risk of serious complications when compared with blade septostomy or the placement of a transseptal stent is significantly less. Third, once the transseptal puncture is performed, this procedure is less challenging and time-consuming than either blade septostomy or balloon dilation with or without stent placement. Fourth, the size of the cannula can be tailored to the size of the patient, allowing for use in smaller patients. Last, this procedure does not leave a large residual atrial septal defect or atrial stent that would need to be addressed if the patient were to recover and be weaned from mechanical support. Because of the elasticity of the atrial septum, the resultant atrial septal defect is smaller than the puncture site ( $5.7 \mathrm{~mm}$ in our patient), which is amenable to device closure in the catheterization laboratory. 


\section{References}

1. Koenig PR, Ralston MA, Kimball TR, Meyer RA, Daniels SR, Schwartz DC. Balloon atrial septostomy for left ventricular decompression in patients receiving extracorporeal membrane oxygenation for myocardial failure. J Pediatr. 1993;122:S95-9.

2. Ward KE, Tuggle DW, Gessouroun MR, Overholt ED, Mantor PC. Transseptal decompression of the left heart during ECMO for severe myocarditis. Ann Thorac Surg. 1995;59:749-51.

3. Booth KL, Roth SJ, Perry SB, del Nido PJ, Wessel DL, Laussen PC.
Cardiac catheterization of patients supported by extracorporeal membrane oxygenation. J Am Coll Cardiol. 2002;40:1681-6.

4. Seib PM, Faulkner SC, Erickson CC, Van Devanter SH, Harrell JE, Fasules JW, et al. Blade and balloon atrial septostomy for left heart decompression in patients with severe ventricular dysfunction on extracorporeal membrane oxygenation. Catheter Cardiovasc Interv. 1999; 46:179-86.

5. Park SC, Neches WH, Mullins CE, Girod DA, Olley PM, Falkowski G, et al. Blade atrial septostomy: collaborative study. Circulation. 1982;66:258-65.

\title{
Robot-assisted endoscopic excision of left atrial myxomas
}

\author{
Douglas A. Murphy, MD, Jeffrey S. Miller, MD, and David A. Langford, MD, Atlanta, Ga
}

$\mathrm{R}$ ecent advances in robotic instrumentation have facilitated endoscopic intracardiac procedures. ${ }^{1,2}$ We report our initial experience with endoscopic left atrial myxoma excision with the da Vinci Surgical System (Intuitive Surgical, Inc, Sunnyvale, Calif).

\section{Clinical Summary}

The clinical characteristics of 3 patients with left atrial masses operated on between September 2003 and May 2004 are presented in Table 1. No patient had preoperative embolic phenomena.

\section{Surgical Technique}

Under general anesthesia with left lung ventilation, the da Vinci endoscope was inserted through a $12-\mathrm{mm}$ port in the fourth intercostal space $2 \mathrm{~cm}$ lateral to the midclavicular line. A $20-\mathrm{mm}$ service port was created lateral to the endoscope in the same interspace. The 2 robotic instrument arms were inserted 1 interspace above and below the endoscope (Figure 1). No ribspreading retractors were used.

The patients were then heparinized and cannulated as previously described for Port Access (Cardiovations, New Brunswick, $\mathrm{NJ}){ }^{3}$ The da Vinci endoscope and instrument arms were then inserted in their respective ports. Insufflation of $\mathrm{CO}_{2}$ into the right pleural space was used to create working space. Pericardium was excised for possible atrial septal reconstruction. The venae cavae were encircled with linen tapes, and total cardiopulmonary bypass,

\footnotetext{
From the Department of Cardiothoracic Surgery, Saint Joseph's Hospital of Atlanta, Atlanta, Ga.

Received for publication Oct 18, 2004; revisions received Nov 30, 2004; accepted for publication Dec 7, 2004.

Address for reprints: Douglas A. Murphy, MD, Department of Cardiothoracic Surgery, Saint Joseph's Hospital of Atlanta, 5665 Peachtree Dunwoody Rd, Atlanta, GA 30342 (E-mail: Dmurphy407@aol.com).

J Thorac Cardiovasc Surg 2005;130:596-7

$0022-5223 / \$ 30.00$

Copyright $\odot 2005$ by The American Association for Thoracic Surgery

doi:10.1016/j.jtcvs.2004.12.005
}

\section{TABLE 1. Patient characteristics}

\begin{tabular}{lccccc}
\hline $\begin{array}{l}\text { Patient } \\
\text { no. }\end{array}$ & Age & Sex & $\begin{array}{c}\text { Clinical } \\
\text { presentation }\end{array}$ & $\begin{array}{c}\text { Tumor size } \\
\text { (cm) }\end{array}$ & Attachment site \\
\hline 1 & 41 & Male & $\begin{array}{c}\text { Near } \\
\text { syncope }\end{array}$ & $3.5 \times 5.0$ & $\begin{array}{c}\text { Interatrial } \\
\text { septum }\end{array}$ \\
2 & 47 & Female & $\begin{array}{c}\text { Arthralgias } \\
\text { Posterocaudal } \\
\text { wall }\end{array}$ \\
3 & 53 & Male & $\begin{array}{c}\text { Near } \\
\text { syncope }\end{array}$ & $3.8 \times 5.6$ & $\begin{array}{c}\text { Interatrial } \\
\text { septum }\end{array}$ \\
\hline
\end{tabular}

intraluminal balloon aortic occlusion, and antegrade cardioplegia were achieved. In the 2 patients with atrial tumors attached to the interatrial septum, exploration was through an oblique right atriotomy for wide exposure of the atrial septum. In both cases, the point of attachment of the tumor could be identified by the presence of abnormal vascularity at the superior pole of the fossa ovalis. Incision was made in the septum medial to the fossa ovalis, and when the left atrium was entered, the incision was extended $360^{\circ}$ around the tumor attachment; 5- to 10-mm margins of normal septal tissue were maintained, with almost no direct instrument contact with the tumor. In the patient with tumor attachment to the posterior left atrial wall, exploration was through a left atriotomy anterior to the pulmonary veins. This tumor was attached to the posterior caudal wall overlying the coronary sinus. Excision was achieved by dissecting a plane though the atrial muscle at the point of attachment. All tumors were grasped by the tissue margins and deposited into an Endopouch Retriever (Ethicon Endo-Surgery, Cincinnati, Ohio) and extracted through the service port. Atrial septal defects created in 2 patients were repaired with autologous pericardial patches. Deairing was ensured with a vent across the mitral valve.

\section{Results}

All intrathoracic components of the operations were completed endoscopically by using robotic instrumentation. Mean cardiopulmonary bypass time was $103 \pm 40$ minutes, and mean aortic occlusion time was $64 \pm 2$ minutes. Postoperative transesophageal echocardiography demonstrated removal of all tumors and intact 